\title{
Delivery method of the placenta in cesarean deliveries and the effect of uterine incision repair area on morbidity: A randomized controlled study
}

\author{
Sezaryen operasyonunda plasentanın doğurtulma yöntemi ve \\ uterin kesi onarım alanının morbiditeye etkisi: Randomize \\ kontrollü bir çalışma
}

\author{
(D) Sadık Kükrer¹, (D) Ayfer Pepekal Kükrer² \\ ${ }^{1}$ University of Health Sciences Turkey, Adana City Training and Research Hospital, Clinic of Obstetrics and Gynecology, Adana, Turkey \\ 2Adana Acrbadem Hospital, Clinic of Obstetrics and Gynecology, Adana, Turkey
}

\begin{abstract}
Objective: We evaluated the effects of spontaneous or manual delivery of the placenta and repair of uterine incision inside or outside the abdomen on intraoperative blood loss, postoperative infection morbidity, and postoperative hospitalization time.

Materials and Methods: We conducted a prospective randomized controlled study with 150 patients among 160 patients who were indicated to undergo emergency cesarean procedures in our tertiary hospital. We divided the patient population into four groups. These four groups were formed by comparing the way the placenta was delivered manually and by spontaneous traction with the repair of the uterus inside and outside the abdomen. Blood loss was determined using quantitative and gravimetric methods. A numeric rating scale was used, which is a one-dimensional method used for uterine sensitivity distribution and pain measurement.

Results: The amount of bleeding was $339 \mathrm{~mL}$ in group 1, $237 \mathrm{~mL}$ in group 2, $470 \mathrm{~mL}$ in group 3, and $490 \mathrm{~mL}$ in group 4, which were significantly different $(\mathrm{p}<0.001)$. The mean surgical time was $30.8 \pm 5.5$ minutes in group $1,30.7 \pm 4.4$ minutes in group $2,38.5 \pm 6.9$ minutes in group 3 , and 43.9 minutes in group $4(\mathrm{p}<0.001)$. When the distribution of uterine tenderness among the groups was examined in the fundus examinations performed on the postpartum $1^{\text {st }}$ day of the patients, we found a significant difference $(\mathrm{p}<0.001)$. When all groups were compared, there was a significant difference between group 1 and group 4 in terms of hospital stay $(\mathrm{p}<0.004)$. Among the contributing factors were endometritis, maternal body weight ( $<<0.053)$, advanced gestational week ( $\mathrm{p}<0.004)$, prolonged surgical time $(\mathrm{p}<0.009)$, and the presence of meconium.

Conclusion: Manual removal of the placenta resulted in higher blood loss, increased uterine tenderness, and longer hospitalization compared with the spontaneous separation method. The uterine incision repair site did not affect morbidity.
\end{abstract}

Keywords: Cesarean section, postpartum hemorrhage, blood loss, endometritis

$\mathrm{O} z$

Amaç: Sezaryen operasyonu esnasında, plasentanın spontan veya manuel yolla doğurtulmasının ve uterin insizyonun batın içinde veya dışında onarımının, intraoperatif kan kaybı, postoperatif enfeksiyon morbiditesi ve postoperatif hastanede kalış süresi üzerindeki etkilerini değerlendirdik.

Gereç ve Yöntemler: Üçüncü basamak hastanemizin kadın hastalıkları ve doğum kliniğinde acil sezaryen operasyonu endikasyonu alan 160 hasta arasından çalışmaya uygun 150 hasta ile prospektif randomize kontrollü çalışma gerçekleştirdik. Hasta popülasyonunu dört gruba ayırdık. Bu dört grup, plasentanın elle ve spontan traksiyon yöntemiyle çıkarılma şekli ile uterus insizyonunun batın içi ve batın dışında onarılması metodlarının karşılaştırılması yoluyla oluşturuldu. Kan kaybı, kantitatif ve gravimetrik yöntemler kullanılarak belirlendi. Uterin hassasiyet dağılımı ve ağrı ölçümü için kullanılan tek boyutlu bir yöntem olan sayısal derecelendirme ölçeği kullanılmıştır.

Bulgular: Kanama miktarı grup l'de 339 mililitre, grup 2'de 237 mililitre, grup 3'te 470 mililitre ve grup 4'te 490 mililitreydi ve farklı bulundu (p<0,001). Ortalama ameliyat süresi grup l'de 30,8 $\pm 5,5$ dakika, grup 2'de 30,7 $\pm 4,4$ dakika, grup 3'te 38,5 $\pm 6,9$ dakika, grup 4'te 43,9 dakika idi (p<0,001). Hastaların postpartum 1. gününde yapılan fundus muayenelerinde uterus hassasiyetinin gruplar arası dağılımı incelediğimizde anlamlı fark bulduk ( $\mathrm{p}<0,001$ ). Tüm

PRECIS: Postoperative morbidity after cesarean operation.

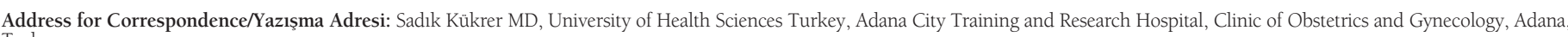
Turkey

Phone: +90 5333236979 E-mail: sadikkukrer@hotmail.com ORCID ID: orcid.org/0000-0001-8465-3225

Received/Geliș Tarihi: 18.01.2021 Accepted/Kabul Tarihi: 13.04.2021

${ }^{\circledR}$ Copyright 2021 by Turkish Society of Obstetrics and Gynecology

Turkish Journal of Obstetrics and Gynecology published by Galenos Publishing House. 
gruplar birbirleri ile karşılaştırıldığında, grup 1 ile grup 4 arasında hastanede kalış süresi açısından anlamlı fark mevcuttu (p<0,004). Endometrit oluşumuna katkıda bulunan faktörler arasında maternal vücut ağırlı̆̆ı $(p<0,053)$, ileri gebelik haftası $(p<0,004)$, uzamış ameliyat süresi ( $p<0,009)$ ve mekonyum varlı̆̆ belirleyicilerdi.

Sonuç: Sezaryen operasyonu esnasında, plasentanın manuel olarak çıkarılmasının, spontan doğurtulma yöntemine göre kıyaslandığında daha fazla kan kaybına, artmıs uterin hassasiyete ve daha uzun süre hastanede kalınmasına neden olmuştur. Uterin kesi onarım bölgesinin morbidite üzerinde etkisi olmadığı belirlendi.

Anahtar Kelimeler: Sezaryen, doğum sonu kanama, kan kaybı, endometrit

\section{Introduction}

The World Health Organization (WHO) reports that since 1985, the cesarean rate that will reduce maternal and infant mortality is between 10 and $15 \%$. According to the systematic review by $\mathrm{WHO}$, it shows that the number of maternal, newborn, and infant deaths in a society decrease when the cesarean rates reach $10-15 \%$. The increase in cesarean delivery rates above this level does not correlate with a decrease in mortality rates. When performed for medical reasons, cesarean section reduces maternal and perinatal mortality and morbidity. However, there is no evidence showing the benefits of cesarean delivery for mothers and babies when cesarean delivery is not required. In recent years, governments and physicians have been reporting an increasing number of cesarean deliveries and the potential negative consequences of cesarean delivery on maternal and child health ${ }^{(1)}$

In Turkey, there is an upward trend, although the rate of cesarean section varies according to the year when we look at the past thirty years. We know that the cesarean rate, which was $5 \%$ in 1988, was over 45\% in 2010. The Turkish Gynecology and Obstetrics Association and the Ministry of Health aimed to reduce this rate with a joint project started in 2011. However, in 2013 , the cesarean rate in our country increased by $35 \%{ }^{(2)}$. In 2017, according to the Organization for Economic Cooperation and Development report, Turkey's cesarean rate increased to $53.1 \%^{(3)}$. Although the relevant institutions and associations of the Ministry of Health have followed a policy of reducing the cesarean rates and took various steps, the desired success has not yet been achieved. Therefore, it has become more valuable to develop surgical techniques to reduce and prevent cesareanrelated morbidity.

Cesarean delivery is a surgical procedure that we perform today, and we see an increase in cesarean delivery rates every year. Given that we cannot reduce our cesarean rate as a delivery method in order not to take risks in terms of medicolegal concerns and maternal and fetal health, we should at least develop ways to reduce the morbidity that may occur for this procedure. The aim of our study, which we created with this hypothesis, was to investigate the effects of spontaneous or manual delivery of the placenta and repair of uterine incision inside or outside the abdomen on intraoperative blood loss, postoperative infection morbidity, and postoperative hospitalization time.

\section{Materials and Methods}

We conducted this prospective randomized study at Adana City Training and Research Hospital Gynecology and Obstetrics Clinic between September 2020 and December 2020. In our hospital, an average of 1100 births per month are performed, and it is an intensive clinic with the characteristics of a tertiary center with 12,000 births per year. We conducted our study together with fourth-year senior assistant physicians under the supervision of the responsible specialist physician and the responsible specialist physician. We obtained approval from the ethics committee of our hospital for the study (Adana City Training and Research Hospital Clinical Research Ethics Committee, 26.08.2020/1047). We received written informed consent form from all volunteers for the study. Our study was conducted in accordance with the Helsinki Declaration Principles.

The study population comprised patients with indications for cesarean delivery who were found to be in active labor. Just before we transported the patient to the operating room, we randomized patients using a computer-generated random number table with the groups determined in closed opaque envelopes. After opening the envelope, the surgeon performed the cesarean section according to the specified group. Group 1 , the placenta was separated spontaneously by traction, and we repaired the uterine incision in the abdomen; group 2 , the placenta was detached spontaneously by traction, and we repaired the uterine incision outside the abdomen; group 3 , the placenta was removed manually, and we repaired the uterine incision in the abdomen; and group 4, the placenta was removed manually, and we repaired the uterine incision outside the abdomen

The study population comprised women with a defined obstetric emergency indication for cesarean delivery. Patients with placental adhesion anomaly, placental detachment, those who received intrapartum antibiotic treatment for any reason, patients with chorioamnionitis, iron deficiency anemia, polyhydramnios, coagulation disorders, uterine atony, uterine leiomyomas, severe heart disease, systemic disease, and those who did not want to be included in the analysis were excluded. We divided cesarean indications into eight major groups. The reason for this was that there were frequently multifactorial factors affecting the mother and fetus in the cesarean indications of the patients. Head-pelvis incompatibility, acute fetal distress, and advanced gestational age indications in the same patient are examples of this situation. In such cases, we 
aimed to emphasize that the result was significant according to the primary indication that led the patient to cesarean section. Otherwise, a different indication group would have had to be created for each patient and this would distract us from the result.

We performed all surgeries under regional spinal anesthesia. We recorded the surgical time as the time from beginning the skin incision to the end of the last suture. During the procedure, we administered 2 grams of cefazolin sodium to all patients as perioperative prophylaxis after the umbilical cord was clamped. After the birth of the fetus, we added 20 international units of oxytocin to intravenous fluids as a uterotonic agent. The hemogram values of the subjects were calculated preoperatively and at the $48^{\text {th }}$ hour after surgery. We examined the difference between the two values.

Blood loss was determined using a quantitative method. We created a dry weight list for cesarean delivery materials that could be wetted with blood to measure blood loss. To determine the actual amount of blood lost, we subtracted the fluid volume from the fluid volume before dispensing the placenta after delivering the placenta. It is important to remember that most of the fluid collected after the birth of the placenta is blood. To determine the cumulative blood volume, we added the wet abdominal compresses and the volume of fluid collected in the aspirator chamber to the measured blood volume by weighing the wetted substances. The number of abdominal compresses and square pads (sponges) used for each operation was noted to determine blood loss. It was determined as 1 gram weight $=1$ milliliter of blood loss volume. The equation used to calculate the blood loss of a substance immersed in blood was as follows: Wet matter gram weight - Dry matter gram weight $=$ Milliliter blood in matter. Identifying blood loss will never be accurate. However, we know that some measurements are more accurate than relying on visual estimates alone ${ }^{(4)}$.

The length of hospital stay (LOS) started at the time of the cesarean section and was reported as the following days. The picture of endometritis was characterized body temperature exceeding $38{ }^{\circ} \mathrm{C}$ twice with an interval of 6 hours, sensitivity of the uterus on bimanual examination and malodorous discharge. We managed subjects with suspected endometritis with triple antibiotics including ampicillin 2 g/i.v. every 6 hours, gentamicin $80 \mathrm{mg}, 1.5 \mathrm{mg} / \mathrm{kg} /$ i.v. every 8 hours, and clindamycin $600 \mathrm{mg} /$ i.v. every 8 hours. Endometrial cultures were not accepted because they brought in uncertain results related to contaminated specimens attained transcervically. After cesarean delivery, the skin incision was checked and wound site infection was checked during dressing on the second day of discharge and the tenth day at the follow-up examination.

A numerical rating scale (NRS) was used, which is a onedimensional method used for uterine sensitivity distribution and pain measurement, according to the groups. On this scale, there are increasing numbers from 0 to 10 spaced on a line. We asked the patients to mark the number on the scale determining the severity of pain. In the numbering form $0-10,0$ was determined as no pain, and 10 as the worst pain imaginable ${ }^{(5)}$. We performed this test on the first postoperative day during routine patient examination and, observed the sensitivity of the uterus while massaging the fundus of the uterus to check whether the uterus was contracting. Then, we marked the uterine sensitivity and pain degrees of the patients and the physicians who conducted the study on this scale.

\section{Statistical Analysis}

One-Way analysis of varinace, the Kruskal-Wallis and chisquare test, Tukey's honestly significant difference (HSD) test, t-test, Levene's test, the Mann-Whitney U test, Fisher's Exact test, and Spearman's correlation coefficients were used in the statistical analysis of the data. We took the level of significance as $\mathrm{p}<0.05$. Data analysis was performed using the SPSS 20.0 statistics package.

\section{Results}

For this study, we identified 160 patients who received cesarean indications according to research criteria. We excluded 10 of these patients because they refused to take part in the study. We excluded nine of the remaining 150 patients because they did not meet the research criteria. Thirty-four patients were in group 1, 36 were in group 2, 30 comprised group 3, and 41 patients made up group 4 (Figure 1).

When we compared the maternal data between groups, we found no significant difference regarding age distribution, parity number, maternal weight, week of gestation time from membrane rupture to cesarean, preoperative hemoglobin ( $\mathrm{Hb})$, and preoperative hematocrit values (Table 1).

When the surgical times were compared in Table 2, we found significant differences between the groups $(p<0.001)$. According to these results, group 4 differed from all other groups and group 3 from groups 1 and 2 according to Tukey's HSD test. When the amount of bleeding was compared using Tukey's HSD test, we found that the bleeding in group 3 differed from that in group 2, and in group 4 from that in groups 1 and 2 . The number of abdominal compresses used differed between the study groups, but there was no difference between the sponges used. For these values in Tukey's HSD test, we saw that groups 2 and 4 differed from group 1 .

When the distribution of birth weights was examined between the groups, we saw that groups 2 and 4 differed from group 1 in Tukey's HSD test. When the distribution of uterine sensitivity was compared between the groups according to the NRS as determined in fundus examinations performed on the first postpartum day, we found a significant difference $(\mathrm{p}<0.001)$. We observed that groups 2 and 3 had a moderate sensitivity rate of $27 \%$ and $18 \%$, whereas group 1 had $76.5 \%$ lower uterine sensitivity, and group 4 had a severe sensitivity rate of $29 \%$. We detected seven (20.6\%) patients with endometritis in group $1,10(27.8 \%)$ group 2 , seven (23.3\%) in group 3, and 15 (36.5\%) patients in group 4 (Table 2 ). 


\section{FLOWCHART}

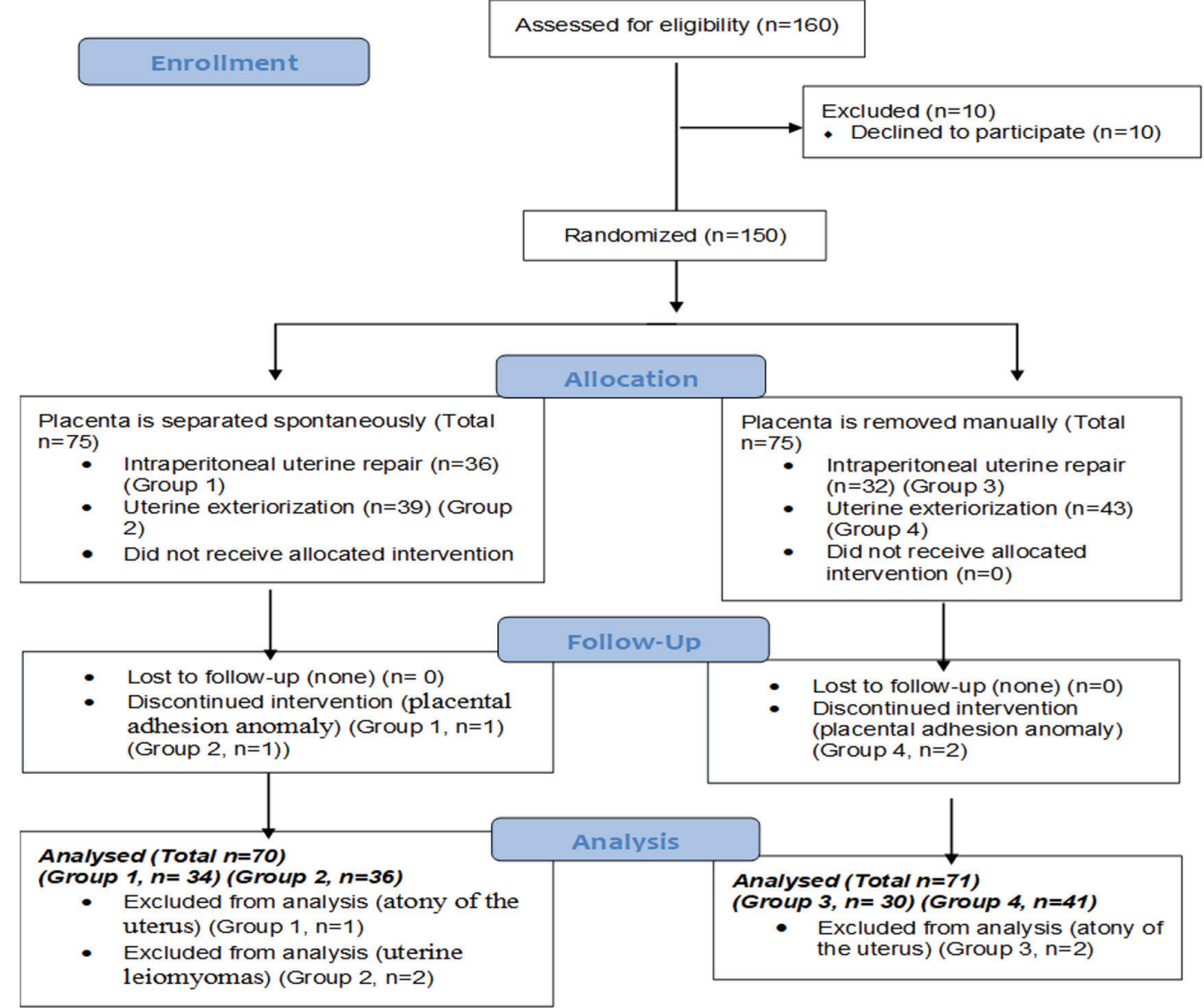

Figure 1. Flowchart

Table 1. Distribution of maternal data between the groups

\begin{tabular}{|c|c|c|c|c|c|c|}
\hline & Group 1 & Group 2 & Group 3 & Group 4 & F ratio & p-value \\
\hline Mother age-year & $27.2 \pm 5.6$ & $27.6 \pm 4.8$ & $27.7 \pm 5.2$ & $27.7 \pm 5.0$ & 0.0722 (ANOVA Test) & 0.9748 (ANOVA) \\
\hline 0 & 13 & 12 & 14 & 17 & & \\
\hline 1 & 14 & 13 & 11 & 12 & & \\
\hline 3 & 1 & 2 & & 3 & & \\
\hline 4 & & 2 & & 2 & & \\
\hline 5 & & & 1 & 1 & & \\
\hline 7 & & 1 & & & & \\
\hline Preoperative - $\mathrm{Hb}(\mathrm{g} / \mathrm{dL})$ & $11.2 \pm 1.4$ & $11.6 \pm 1.5$ & $11.5 \pm 1.1$ & $11.2 \pm 1.3$ & 0.6903 (ANOVA) & 0.5594 (ANOVA) \\
\hline Preoperative -Htc (\%) & $33.9 \pm 4.0$ & $35.2 \pm 4.1$ & $34.2 \pm 3.4$ & $33.7 \pm 3.6$ & 1.1250 (ANOVA) & 0.3413 (ANOVA) \\
\hline
\end{tabular}

$\mathrm{Hb}$ : Hemoglobin 
Table 2. Intrapartum-Postpartum criteria and statistical value

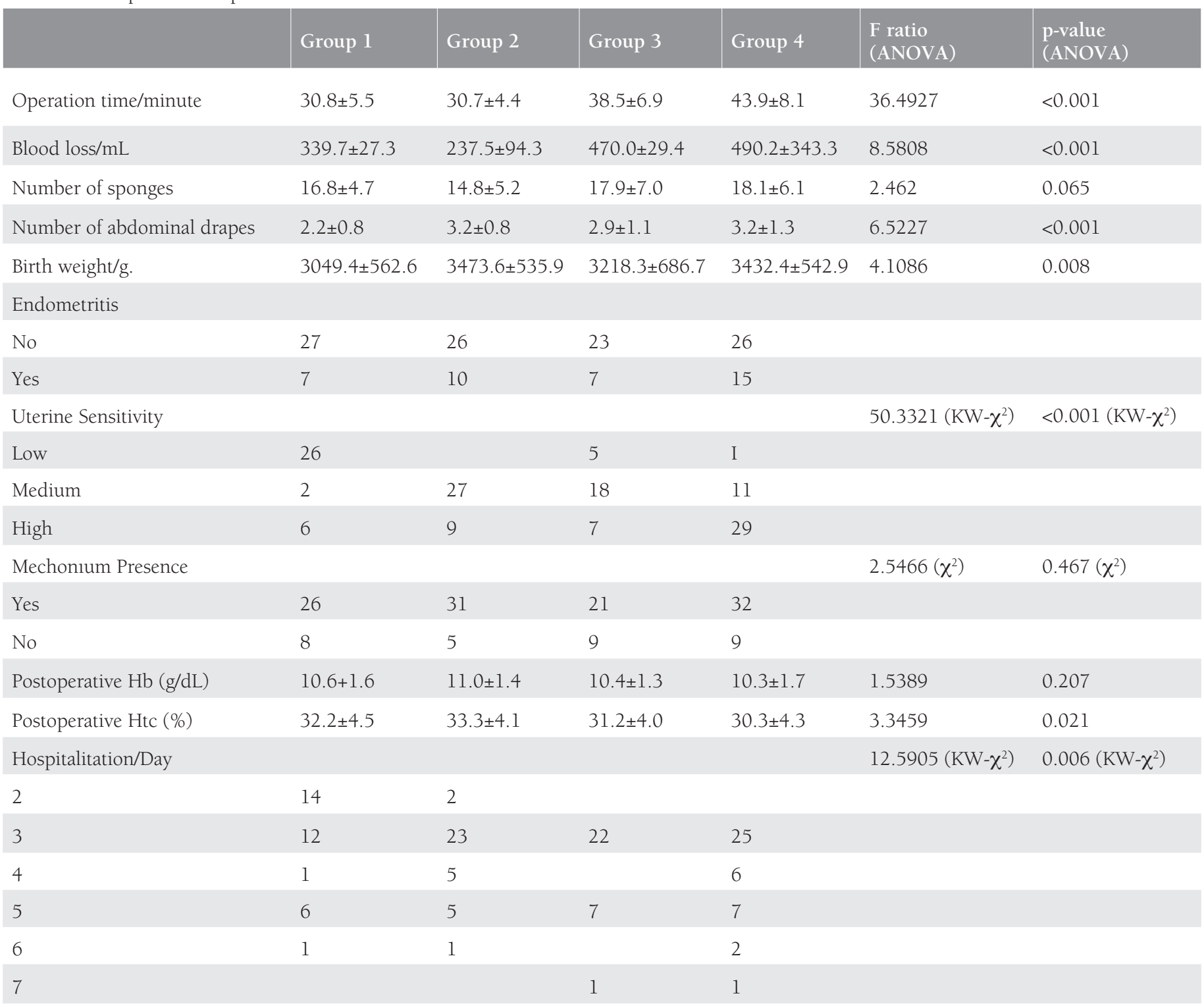

In the postoperative period, there was a significant difference in hematocrit (Htc, \%) values in group 2 compared with group 4 ( $<<0.021$ ). Among the methods performed, we saw the most bleeding in the postoperative period in group 4. Endometritis and the factors affecting it are presented in Table 2 and Table 3 (Graphic 1, 2).

We also compared these parameters with maternal characteristics and intrapartum features. One parameter that affected the amount of blood loss that accumulated in the aspirator was maternal weight another was surgical time. Only surgical time caused a significant increase in the number of sponges used. The first parameter affecting the number of abdominal compresses used in the surgery was maternal weight, followed by surgical time and birth weight. Another feature of the number of compresses used was that it increased uterine sensitivity (Graphic 3).
The Presence of Endometritis Graphic 1

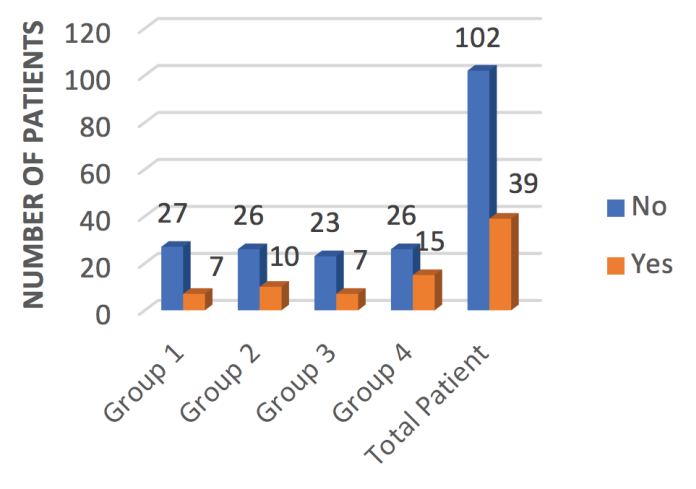

Graphic 1. The presence of endometritis 


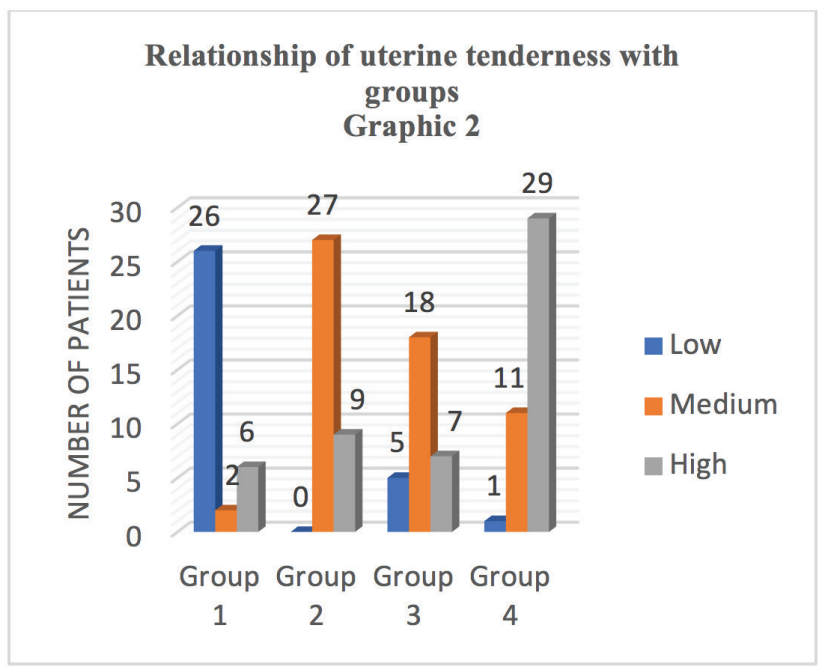

Graphic 2. Relationship of uterine tenderness with groups

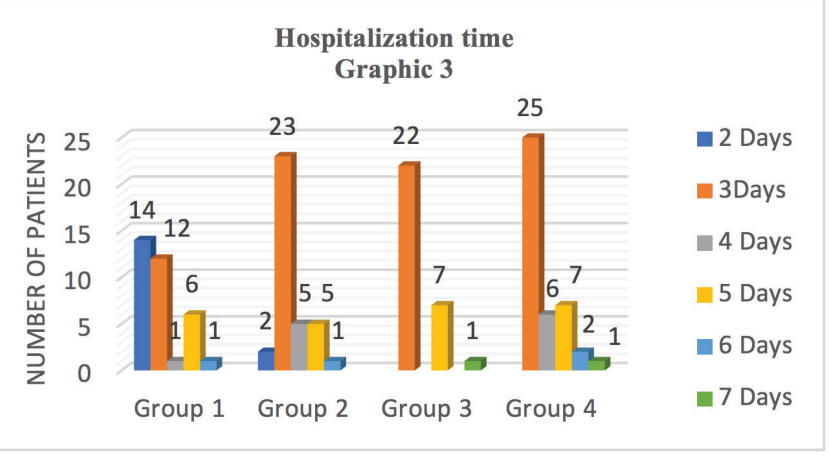

Graphic 3. Hospitalization time

There was one patient with wound infection in group 1, 2 and 3 , we observed wound infection in three patients in group 4 . When all groups were compared, LOS was different between groups 1 and $4(\mathrm{p}<0.004)$ (Graphic 4).

We observed a significant decrease in $\mathrm{Hb}$ and Htc values in the postoperative period compared with before the operation, and a significant increase in white blood cell values. We tested these values as the expected normal result of the procedure. However, another striking finding was that although there was a non-significant decrease in platelet values in group 1, 2, and 3 when compared using the paired t-test, there was a significant decrease in group 4 (Table 3).

We compared the effects of maternal criteria and intrapartum features on endometritis using the two-tail t-test (Table 4). We determined that the increase in maternal body weight was effective in creating endometritis $(\mathrm{p}<0.053)$ and we encountered more endometritis in advanced weeks of gestation $(p<0.004)$. Prolonged surgical time was another factor that contributed to creating endometritis ( $\mathrm{p}<0.009)$.

As seen in Table 5, we found no significant difference between parity and endometritis. However, a significant relationship was found between the existence of meconium and endometritis $(\mathrm{p}<0.001)$ (Table 6).

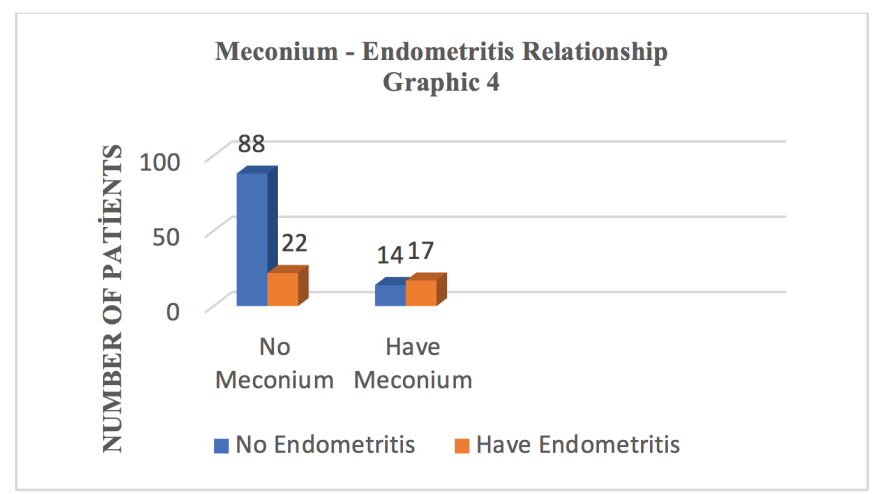

Graphic 4. Meconium-endometritis relationship

Table 3. Comparison of preoperative and postoperative values of complete blood count with intergroup paired t-test

\begin{tabular}{|c|c|c|c|c|}
\hline & Group 1 & Group 2 & Group 3 & Group 4 \\
\hline $\begin{array}{l}\text { Preop. } \\
\mathrm{Hb} \\
(\mathrm{g} / \mathrm{dL})\end{array}$ & 11.25 & 11.66 & 11.51 & 11.28 \\
\hline $\begin{array}{l}\text { Postop. } \\
\mathrm{Hb} \\
\text { (g/dL) }\end{array}$ & 10.66 & 11.05 & 10.46 & 10.31 \\
\hline $\begin{array}{l}\text { t-test } \\
\text { (p-value) }\end{array}$ & 0.001 & 0.001 & 0.001 & 0.001 \\
\hline $\begin{array}{l}\text { Preop. } \\
\text { Htc. (\%) }\end{array}$ & 33.99 & 35.28 & 34.28 & 33.76 \\
\hline $\begin{array}{l}\text { Postop. } \\
\text { Htc. (\%) }\end{array}$ & 32.23 & 33.38 & 31.28 & 30.39 \\
\hline $\begin{array}{l}\text { t-test } \\
\text { (p-value) }\end{array}$ & 0.001 & $<0.001$ & $<0.001$ & $<0.001$ \\
\hline $\begin{array}{l}\text { Preop. } \\
\text { Wbc } \\
\mathrm{mm}^{3}\end{array}$ & 12282.35 & 10663.89 & 11190.00 & 11773.17 \\
\hline $\begin{array}{l}\text { Postop. } \\
\text { Wbc } \\
\text { mm }^{3}\end{array}$ & 15314.71 & 14086.11 & 13623.33 & 14031.71 \\
\hline $\begin{array}{l}\text { t-test } \\
\text { (p-value) }\end{array}$ & $<0.001$ & $<0.001$ & 0.001 & 0,0001 \\
\hline $\begin{array}{l}\text { Preop. } \\
\text { Plt. mm }{ }^{3}\end{array}$ & $227,000.00$ & $236,111.11$ & $208,600.00$ & $220,146.34$ \\
\hline $\begin{array}{l}\text { Postop. } \\
\text { Plt. } \text { mm }^{3}\end{array}$ & $226,147.06$ & $234,388.89$ & 198633.33 & 204439.02 \\
\hline $\begin{array}{l}\text { t-test } \\
\text { (p-value) }\end{array}$ & 0.886 & 0.816 & 0.142 & 0.008 \\
\hline
\end{tabular}

Hb: Hemoglobin, Preop: Preoperative, Postop: Postoperative, Wbc: White blood cell, Plt: Platelet

Among the cesarean indication groups, pregnant mothers with preeclampsia and severe preeclampsia made up 2.9\% of group 1 . Twenty-two pregnant women with head-pelvis incompatibility made up $16.2 \%$ of group 2. Patients who became pregnant after 
Table 4. The relationship between maternal-intrapartum characteristics and the presence of endometritis

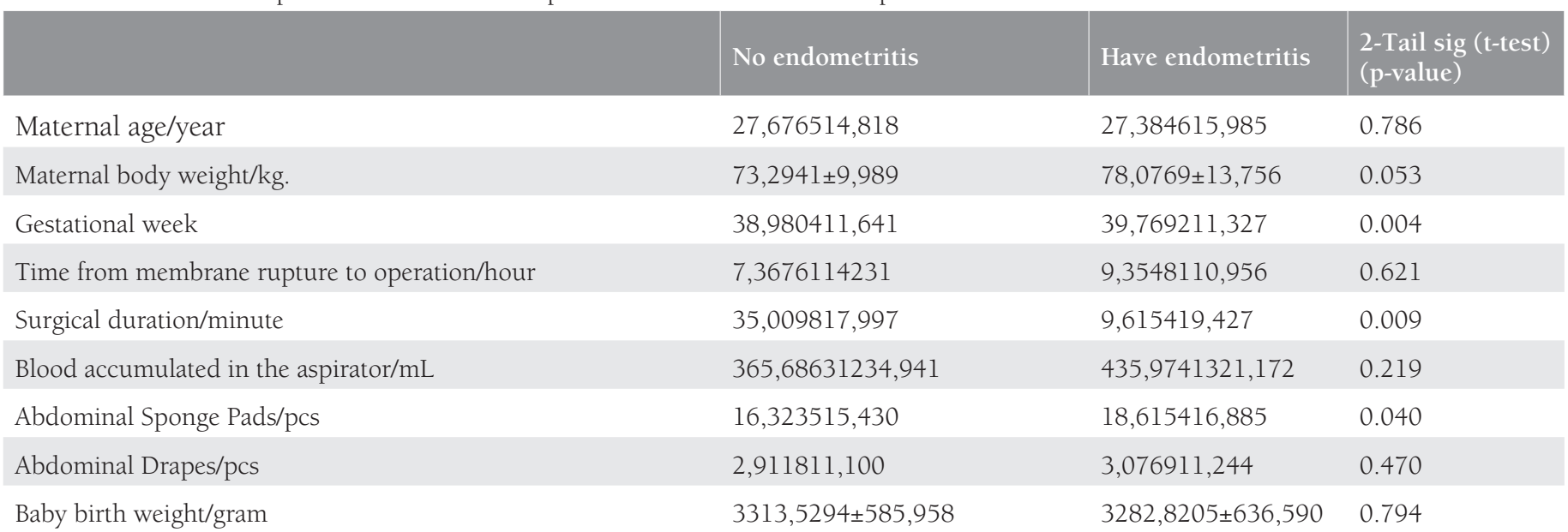

Table 5. Parity-endometritis relationship

\begin{tabular}{|c|c|c|c|}
\hline \multicolumn{4}{|c|}{ Parity/endometritis ratio } \\
\hline & $\begin{array}{l}\text { No } \\
\text { Endometritis }\end{array}$ & $\begin{array}{l}\text { Have } \\
\text { Endometritis }\end{array}$ & $\begin{array}{l}\text { 2-Tailed P Mann- } \\
\text { Whitney U-test. } \\
\text { p-value }\end{array}$ \\
\hline $\begin{array}{l}\text { Number of } \\
\text { Parity }\end{array}$ & & & 0.801 \\
\hline 0 & 37 & 19 & \\
\hline 1 & 43 & 7 & \\
\hline 2 & 14 & 8 & \\
\hline 3 & 2 & 19 & \\
\hline 4 & 4 & 0 & \\
\hline 5 & 1 & 1 & \\
\hline 7 & 1 & 0 & \\
\hline
\end{tabular}

receiving primary infertility treatment and those whose age was over 35 years made up group 3. Forty-seven women who had a previous cesarean delivery made up group 4 with a rate of $47 \%$. Forty women with acute fetal distress made up group 5 with a rate of $40 \%$. Four women who underwent cesarean due to multiple pregnancies made up group 6 with 4\%. Eleven women with primigravid breech presentation and other presentation anomalies made up group 7 with $11 \%$. Two women with intrauterine growth restriction made up group 8 with $2 \%$.

We tested the endometritis picture within these groups. Among the cesarean groups, we observed endometritis in 18 (47.4\%) of the women who underwent cesearean with the diagnosis of AFD. The other two most common indications for endometritis were head-pelvis incompatibility in nine $(23.7 \%)$ women and presentation anomalies in four women (10.5\%). Maternal and intrapartum features affecting endometritis are shown in Tables 4,6 , and 7 .

As seen in Table 7 , only the gestational week was found associated with endometritis $(\mathrm{p}<0.031)$. However, as seen in Table 4 , the
Table 6. Meconium-endometritis relationship

\begin{tabular}{l|l|l|l|}
\hline \multicolumn{4}{|l|}{ Meconium-endometritis relationship } \\
$\begin{array}{l}\text { No } \\
\text { Endometritis }\end{array}$ & Endometritis & $\begin{array}{l}\text { Chi-square } \\
\text { test p-value }\end{array}$ \\
\hline No meconium & 88 & 22 & 0.00013 \\
Meconium & 14 & 17 &
\end{tabular}

Table 7. The effect of maternal and intrapartum characteristics on endometritis collectively

\begin{tabular}{|l|l|l|}
\hline & $\begin{array}{l}\text { Chi-square test } \\
\text { f-value }\end{array}$ & $\begin{array}{l}\text { Chi-square test } \\
\text { p-value }\end{array}$ \\
\hline $\begin{array}{l}\text { Patient weight/kg } \\
\begin{array}{l}\text { Time from membrane } \\
\text { rupture to operation/hour }\end{array}\end{array}$ & 0.007 & 0.828 \\
\hline $\begin{array}{l}\text { Operation time/minute } \\
\text { Gestational week }\end{array}$ & 0.048 & 0.162 \\
\hline $\begin{array}{l}\text { Abdominal sponges/pcs } \\
\text { Meconium presence }\end{array}$ & 0.110 & 0.833 \\
\hline Operation type (group) & 0.574 & 0.031 \\
\hline
\end{tabular}

results were more significant when the time from membrane rupture, which had no direct effect on the procedure, was excluded group (Table 8). As seen in Table 9, when membrane rupture was excluded, surgical duration $(\mathrm{p}<0.041)$, gestational week $(\mathrm{p}<0.057)$, and meconium $(\mathrm{p}<0.001)$ were effective on endometritis.

When the cesarean groups were added to the parameters in Table 8, we found that they affected the creation of endometritis (Table 9). In our study, we determined that prolonged surgical duration and the presence of meconium in amniotic fluid contributed to the formation of endometritis. 
Although none of the maternal and intrapartum features affected the postoperative $\mathrm{Hb}$ concentration, only surgical duration affected the postoperative Hct percentage. Accordingly, we determined that the increase in surgical duration made a significant difference in all parameters except $\mathrm{Hb}$ concentration, which is affected by the amount of bleeding (Table 10).

\section{Discussion}

In our study, the method of delivering the placenta during cesarean section clinically and statistically affected operative

Table 8. Presence of endometritis (rupture of membranes were excluded)

\begin{tabular}{|l|l|l|} 
& $\begin{array}{l}\text { Chi-square } \\
\text { test f-value }\end{array}$ & $\begin{array}{l}\text { Chi-square } \\
\text { test p-value }\end{array}$ \\
\hline Maternal weight/kg & 0,0135 & 0.475 \\
\hline Surical duration/minute & 0,0760 & 0.041 \\
\hline Gestational week & 0,3091 & 0.057 \\
\hline Abdominal sponges/pcs & 0,0501 & 0.208 \\
\hline Meconium presence & 0,8238 & 0.001 \\
\hline Operation type (group) & & 0.417
\end{tabular}

Table 9. Parameters affecting endometritis when cesarean indication groups were included in the study

\begin{tabular}{lll} 
& $\begin{array}{l}\text { Chi-square } \\
\text { test f-value }\end{array}$ & $\begin{array}{l}\text { Chi- } \\
\text { square test } \\
\text { p-value }\end{array}$ \\
\hline Maternal weight/kg & 0.0194 & 0.368 \\
Operation time/minute & 0.0970 & 0.032 \\
Gestational week & 0.1946 & 0.274 \\
Abdominal sponges/pcs & 0.0768 & 0.105 \\
Meconium presence & 0.6666 & 0.022 \\
Operation type (group) & & 0.351 \\
Cesarean indication group & & 0.198
\end{tabular}

blood loss, surgical duration, endometritis formation, and LOS. Although we found an increase in all these parameters in the groups in which the placenta was removed manually, we saw that the uterine repair site had no direct clinical effect on patients undergoing cesarean section.

There are varied forms of cesarean surgery, so the selected procedures can cause particular morbidity related to this procedure. The technique of separating the placenta is an essential process that could contribute to acceleration or maybe a reduction in cesarean morbidity ${ }^{(6)}$. The form of placental removal during cesarean birth is even a controversial issue because previous research has reported uncertain and heterogeneous results ${ }^{(7)}$. In our research, while investigating the specifications that influenced bleeding, we examined the average blood volume in the aspirator chamber, the number of abdominal sponges and compresses used in the procedure, preoperative and postoperative complete blood count values, and surgical groups.

There are many approaches to establishing the quantity of blood loss during cesarean section ${ }^{(8)}$. The American College of Obstetricians and Gynecologists authorizes the meaningful recommendations and concerns. They claimed that quantitative procedures of testing obstetric blood loss were more precise than visual estimates in measuring obstetric blood loss. Studies that analyzed visual assessments for quantitative appraisal found that visual estimates were more likely to underestimate the correct blood loss when amounts were serious and overestimate when amounts were low. Although quantitative assessment is more accurate than visual assessment for measuring obstetric blood loss, the efficacy of quantitative blood loss assessment has not been shown in scientific studies ${ }^{(9)}$. During this investigation, we accepted gravimetric and volumetric approaches to analyze intraoperative blood loss ${ }^{(10)}$. We believe this method is practical in terms of applicability and accurate enough to measure intraoperative blood loss.

In line with the information in the literature, we saw that the amount of bleeding increased when we manually removed the placenta from the uterus ${ }^{(7,11)}$. While there was no difference

Table 10. Statistical evaluation of the parameters affecting bleeding

\begin{tabular}{|c|c|c|c|c|c|}
\hline & $\begin{array}{l}\text { Blood accumulated } \\
\text { in the aspirator/ } \\
\mathrm{mL} \chi^{2}\end{array}$ & $\begin{array}{l}\text { Abdominal Sponge } \\
\text { Pads/pcs } \chi^{2}\end{array}$ & $\begin{array}{l}\text { Abdominal } \\
\text { Compress/pcs } \chi^{2}\end{array}$ & $\begin{array}{l}\text { Postop. Hb (g/ } \\
\text { dL) } \chi^{2}\end{array}$ & $\begin{array}{l}\text { Postop. Htc } \\
(\%) \chi^{2}\end{array}$ \\
\hline Maternal age/year & 0.271 & 0.205 & 0.138 & 0.881 & 0.528 \\
\hline Parity number parity & 0.263 & 0.898 & 0.108 & 0.448 & 0.527 \\
\hline Gestational week & 0.817 & 0.135 & 0.507 & 0.900 & 0.992 \\
\hline Operation time/minute & 0.0001 & 0.029 & 0.013 & 0.088 & 0.003 \\
\hline Baby birth weight/g & 0.317 & 0.564 & 0.008 & 0.931 & 0.859 \\
\hline Uterine tenderness & 0.108 & 0.252 & 0.007 & 0.454 & 0.095 \\
\hline
\end{tabular}


in the number of sponges used, the number of abdominal compresses used in group 4 and group 2 differed from group 1 ( $\mathrm{p}<0.001)$. Although it was a clinical finding, we expected this for group 4, in which we removed the placenta manually, but we did not expect this for group 2, where we separated the placenta spontaneously. In both groups, the repair of the uterine incision outside the abdomen was remarkable in terms of the importance of the uterine repair site in bleeding ${ }^{(12-15)}$.

In the study conducted by Baksu et al. ${ }^{(16)}$, the authors found that the decrease in $\mathrm{Hb}$ values in the postoperative period in the groups in which the placenta was separated by itself was statistically different from the groups in which the placenta was separated manually $(\mathrm{p}<0.05)^{(16)}$. In our study, we found no statistical difference in the decrease in $\mathrm{Hb}$ values. However, when the decrease in Hct values was compared in the groups in which the placenta was removed manually, the difference was statistically significant $(\mathrm{p}<0.001)$. There was also no significant difference between the decrease in postoperative Hct values in the extra-abdominal and intra-abdominal groups after repair of the uterine incision line $(\mathrm{p}=0.83)$.

McCurdy et al. ${ }^{(17)}$ found that the estimated blood loss was higher in the manual removal group compared with the group that spontaneously removed the placenta during cesarean delivery. However, they reported that the decrease in $\mathrm{Hb}$ values was higher at the postoperative $48^{\text {th }}$ hour in the group in which the placenta was removed manually, contrary to our study ${ }^{(17)}$. Wilkinson and Enkin. ${ }^{(18)}$ stated in their research that uterine incision repair performed outside the abdomen had no significant effect on blood loss. However, they expressed that manual removal of the placenta was correlated with a considerable increase in maternal blood loss ${ }^{(19,20)}$. In their 2004 study, Dehbashi et al. and Morales et al. ${ }^{(20,21)}$ found that the groups in which the placenta was removed manually had over $1000 \mathrm{~mL}$ of blood loss.

Some investigators reported that the method of placental management after delivery of the fetus might still be an efficient part of the etiology of post-cesarean endometritis(22). When prophylactic antibiotics are not administered, the incidence of endometritis after cesarean section is $20-40 \%{ }^{(23)}$. In contrast with placebo or no treatment, the benefit of prophylactic antibiotics in women undergoing cesarean section reduced the percentage of wound infection, endometritis, and serious infectious complications by $60 \%$ to $70 \%^{(24)}$. Researchers confirmed that manual removal of the placenta was associated with an increased incidence of post-cesarean endometritis compared with spontaneous removal of the placenta ${ }^{(19,20)}$. By contrast, Gün et al. ${ }^{(25)}$ showed that manual removal of the placenta was not associated with postpartum blood loss and infection development compared with the spontaneous separation method.

We determined that the prolongation of surgical duration caused a significant increase, creating endometritis and more blood loss during the procedure $(\mathrm{p}<0.009)$. Ramadani ${ }^{(26)}$ stated that surgical duration was significantly shorter in the group in which the placenta was removed manually $(40.0 \pm 3.0$ minutes $)$ compared with the group in which the placenta was separated spontaneously (45.0 \pm 4.0 minutes). Ramadani ${ }^{(26)}$ investigated the relationship between blood loss during cesarean and the method of placental separation and described similar results. The authors declared that the blood loss correlated with spontaneous separation and manual removal of the placenta was $(702 \pm 250$ milliliters $)$ and $(710 \pm 243 \text { milliliters })^{(26)}$. Darj and Nordstrom $^{(27)}$ also stated this in their studies. Tran et al. ${ }^{(28)}$ found that the risk of postoperative infection increased 2.4 times in every procedure where cesarean delivery lasted more than an hour. Although it is stated in the literature that endometritis is more common in nulliparas women, we observed no significant difference in our study ${ }^{(29)}$.

\section{Study Limitations}

One limitation of our investigation was the variations in the capability of the surgical team to perform the cesarean section. Although all obstetricians who adhered to the method were at the same academic and scientific status, it was difficult to control the skill and promptness. It was not possible to conduct the research with a single obstetrician performing all these operations to reduce skill diversity among operators. There is no unique standard technique for testing blood loss but we used methods to measure the defined variables in our research. Another limitation of this study is to investigate surgical blood loss in a healthy patient population without known additional risk factors. Patients with excessive blood loss for additional risk factors in the studied population were not included in the study and therefore we did not use different quantitative measurement techniques for this condition. Finally, it is not possible to avoid any other fetal body fluid such as amniotic fluid or fetal urine. If we include these fluids in blood loss, the results may be erroneous.

\section{Conclusion}

Manual removal of the placenta leads to a clinically and statistically high rate of operative blood loss, surgical duration, increased uterine sensitivity, and LOS. We observed the least blood loss when the placenta was delivered spontaneously and we repaired the uterine incision outside the abdomen. Other factors that affect bleeding are the mother's weight, the baby's birth weight, and surgical duration. We associate the prolongation of surgical duration with increased febrile morbidity and the amount of bleeding.

We found that the method in which the placenta was separated spontaneously and the uterine incision was repaired outside the abdomen resulted in the shortest surgical duration and the least blood loss.

Cesarean delivery is a major predisposing clinical factor in terms of the frequency and severity of pelvic infection. Among the cesarean delivery indications, cephalopelvic disproportion 
and fetal distress create the most endometritis. Other factors that affect the formation of endometritis include gestational week, surgical duration, the presence of meconium in amniotic fluid, and the mother's weight. Parity number, the time from membrane rupture to cesarean delivery, and surgical groups did not affect endometritis statistically. Delivering the placenta with a manual method and repairing the uterine incision outside the abdomen caused the most clinical postoperative endometritis. The uterine repair site has no significant statistical effect on postoperative endometritis, surgical duration, and operative blood loss.

\section{Acknowledgements}

I would like to thank the valuable assistant doctors who helped me at every stage of the study, Associate Professor Doctor Veli Mihmanl, Doctor Ayfer Pepekal Kükrer, Adana City Hospital surgery nurses and operating room auxiliary service staff.

\section{Ethics}

Ethics Committee Approval: We obtained approval from the ethics committee of our hospital for the study (Adana City Training and Research Hospital Clinical Research Ethics Committee, 26.08.2020/1047).

Informed Consent: We received written informed consent form from all volunteers for the study.

Peer-review: Externally and internally peer-reviewed.

\section{Authorship Contributions}

Surgical and Medical Practices: S.K., Concept: S.K., Design: S.K., Data Collection or Processing: S.K., Analysis or Interpretation: A.P.K., Literature Search: A.P.K., Writing: S.K.

Conflict of Interest: The authors report no conflict of interest. Financial Disclosure: Authors have no financial interests about the research.

\section{References}

1. WHO Statement on caesarean section rates. Reproductive health matters. World Health Organization 2015;23:149-50.

2. Küçükbaş GN, Moraloğlu Ö, Özel Ş, Erkaya S, Taşcı Y, Fındık RB. The cesarean rates and indications between 2010 and 2014 in the Obstetrics Department of Dr. Zekai Tahir Burak Maternal Health Training and Research Hospital. Perinat 2016;24:61-5.

3. OECD. OECD iLibrary | Caesarean sections. OECD iLibrary | Caesarean sections, 2020. Last Accessed Date: 01.09.2020. Available from: https://www.oecd-ilibrary.org/social-issues-migration-health/ caesarean-sections/indicator/english_adc3c39f-en.

4. Quantification of blood loss: AWHONN practice brief number 1. J Obstet Gynecol Neonatal Nurs 2015;44:158-60.

5. Hartrick CT, Kovan JP, Shapiro S. The numeric rating scale for clinical pain measurement: a ratio measure? Pain Pract 2003;3:3106.

6. Anorlu RI, Maholwana B, Hofmeyr GJ. Methods of delivering the placenta at caesarean section. Cochrane Database Syst Rev 2008:CD004737. doi: 10.1002/14651858.CD004737.pub2.

7. Kanwal S, Naseer Awan S, Sadiqa Batool S. Efficacy of different placental removal methods in terms of blood loss during caesarean section. Pak Armed Forces Med J 2020;70:578-83.
8. Gerdessen L, Meybohm P, Choorapoikayil S, Herrmann E, Taeuber I, Neef V, et al. Comparison of common perioperative blood loss estimation techniques: a systematic review and meta-analysis. J Clin Monit Comput 2021;35:245-58.

9. Quantitative blood loss in obstetric hemorrhage: ACOG COMMITTEE OPINION, number 794. Obstet Gynecol 2019;134:E150-6. doi: 10.1097/AOG.0000000000003564.

10. Doctorvaladan S, Jelks A, Hsieh E, Thurer R, Zakowski M, Lagrew D. Accuracy of blood loss measurement during cesarean delivery. Am J Perinatol Rep 2017;7:e93-100. doi: 10.1055/s-0037-1601382.

11. Ashraf S, Awan AS, Tabassum H, Ashraf O, Fatima T Shadab W. Comparison of blood loss in manual and spontaneous removal of placenta in caesarean section. Journal Rawalpindi Medical College 2020;24:80-4.

12. Zaphiratos V, George RB, Boyd JC, Habib AS. Extériorisation de l'utérus vs. réparation in situ lors de césarienne: revue systématique et méta-analyse. Can J Anesth 2015;62:1209-20.

13. Abdellah MS, Abbas AM, Ali MK, Mahmoud A, Abdullah SA. Uterine exteriorization versus intraperitoneal repair: effect on intraoperative nausea and vomiting during repeat cesarean delivery - A randomized clinical trial. Facts Views Vis Obyn 2018;10:131-7.

14. El-Khayat W, Elsharkawi M, Hassan A. A randomized controlled trial of uterine exteriorization versus in situ repair of the uterine incision during cesarean delivery. Int J Gynecol Obstet 2014;127:163-6.

15. Nafisi S. Influence of uterine exteriorization versus in situ repair on post-cesarean maternal pain: a randomized trial. Int J Obstet Anesth 2007;16:135-8

16. Baksu A, Kalan A, Ozkan A, Baksu B,Tekelioğlu M, Goker N. The effect of placental removal method and site of uterine repair on postcesarean endometritis and operative blood loss. Acta Obstet Gynecol Scand 2005;84:266-9.

17. McCurdy CM, Magann EF, McCurdy CJ, Saltzman AK. The effect of placental management at cesarean delivery on operative blood loss. Am J Obstet Gynecol 1992:167:1363-7.

18. Wilkinson C, Enkin M. Uterine exteriorization versus intraperitoneal repair at caesarean section. Cochrane Database Syst Rev 2000:CD000085. doi: 10.1002/14651858.CD000085.

19. Dahlke JD, Mendez-Figueroa H, Rouse DJ, Berghella V, Baxter JK, Chauhan SP. Evidence-based surgery for cesarean delivery: an updated systematic review. Am J Obstet Gynecol 2013;209:294306.

20. Dehbashi S, Honarvar M, Fardi FH. Manual removal or spontaneous placental delivery and postcesarean endometritis and bleeding. Int J Gynecol Obstet 2004;86:12-5.

21. Morales M, Ceysens G, Jastrow N, Viardot C, Faron G, Vial Y, et al. Spontaneous delivery or manual removal of the placenta during caesarean section: A randomised controlled trial. BJOG 2004;111:908-12.

22. Lasley DS, Eblen A, Yancey MK, Duff P. The effect of placental removal method on the incidence of postcesarean infections. Am J Obstet Gynecol 1997;176:1250-4.

23. Magann EF, Dodson MK, Harris RL, Floyd RG, Martin JN, Morrison JG. Does Method of Placental Removal or Site of Uterine Incision Repair Alter Endometritis After Cesarean Delivery? Infect Dis Obstet Gynecol 1993;1:65-70.

24. Smaill FM, Gyte GM. Antibiotic prophylaxis versus no prophylaxis for preventing infection after cesarean section. Cochrane Database Syst Rev 2010:CD007482. doi: 10.1002/14651858.CD007482.pub2. 
25. Gün I, Özdamar Ö, Ertuğrul S, Öner Ö, Atay V. The effect of placental removal method on perioperative hemorrhage at cesarean delivery; a randomized clinical trial. Arch Gynecol Obstet 2013;288:563-7.

26. Ramadani H. Cesarean section intraoperative blood loss and mode of placental separation. Int J Gynecol Obstet 2004;87:114-8.

27. Darj E, Nordstrom ML. The Misgav Ladach method for cesarean section compared to the Pfannenstiel method. Acta Obstet Gynecol Scand 1999;78:37-41.
28. Tran TS, Jamulitrat S, Chongsuvivatwong V, Geater A. Risk factors for postcesarean surgical site infection. Obstet Gynecol 2000;95:367-71.

29. Chang PL, Newton ER. Predictors of antibiotic prophylactic failure in post-cesarean endometritis. Obstet Gynecol 1992;80:117-22. 